\title{
PERALIHAN HAK ATAS TANAH MELALUI JUAL BELI BERDASARKAN HUKUM ADAT
}

\author{
I Made Krishna Dharma Kusuma, Putu Gede Seputra, Luh Putu Suryani \\ Fakultas Hukum Universitas Warmadewa, Denpasar-Bali, Indonesia
}

\begin{abstract}
Abstrak
Manusia tidak bisa lepas dari yang namanya tanah, karena tanah itu sendiri yang menghidupkan manusia dan makluk hidup di sekitarnya. Dalam kemajuan jaman masa kini tanah memiliki nilai ekonomis. Tanah merupakan modal utama dan terbesar dari Indonesia, dan tanah merupakan modal satu-satunya. Permasalahan yang dikaji dalam penelitian ini adalah tata cara peralihan hak atas tanah menurut hukum adat dan kekuatan hukum jual beli hak milik atas tanah menurut hukum adat. Metode penelitian yang digunakan adalah metode penelitian hukum normatif, teknik pengumpulan data ialah studi kepustakaan yang dilakukan untuk mengumpulkan bahan hukum primer dan sekunder. Hasil penelitian menunjukkan bahwa peralihan hak atas tanah menurut hukum adat itu sah jika melakukan tindakan terang dan diwujudkan dengan uang tunai. Yang dimaksud dengan ialah perjanjian jual-beli tersebut harus dilakukan di hadapan PPAT (Pejabat Pembuat Akta Tanah) dan ada saksi dalam peralihan hak atas tanah itu dan saksinya adalah kepala desa dan masyarakat setempat tersebut. Sedangkan yang di maksud tunai adalah adanya dua perbuatan yang dilakukan secara sejalan yaitu pemindahan hak dari si penjual kepada si pembeli dan pembayaran harga, baik sebagian maupun seluruhnya, dari pembeli diberikan kepada penjual. Tindakan jual beli yang beritikad baik terlihat pada saat para pihak yang melakukan jual-beli hak atas tanah meminta untuk dilakukan di hadapan kepala adat/kepala desa setempat. Di dalam KUHPerdata, perlindungan hukum diberikan terhadap pembeli yang beritikad baik, apabila perjanjian jual beli dilakukan berdasarkan Hukum Adat telah dilindungi oleh ketentuan Pasal 1338 ayat (3) KUHPerdata.
\end{abstract}

Kata Kunci: Peralihan Hak; Tanah; Hukum Adat

\begin{abstract}
Humans are inseparabale to land, because the land itself is what animates humans and the living things around it. In today's progress, land has economic value. Land is the main and largest capital of Indonesia, and land is the only capital. The problems examined in this research are the procedures for transferring rights to land according to customary law and the legal force of the sale and purchase of land rights according to customary law. The research method used is normative legal research methods, data collection techniques are literature studies conducted to collect primary and secondary legal materials. The results showed that the transfer of rights to land according to customary law was legal if it took an explicit act and was manifested in cash. What is meant by is that the sale and purchase agreement must be made before the PPAT (Land Deed Maker Official) and there is a witness in the transfer of rights over the land and the witness is the village head and the local community. Meanwhile, what is meant by cash is that there are two actions that are carried out in parallel, namely the transfer of rights from the seller to the buyer and the payment of price, either partially or completely, from the buyer to the seller. The act of buying and selling in good faith can be seen when the parties carrying out the sale and purchase of land rights ask to be carried out in front of the local customary / village head. In the Civil Code, legal protection is given to buyers with good intentions, if the sale and purchase agreement is made based on Customary Law, it has been protected by the provisions of Article 1338 paragraph (3) of the Civil Code.
\end{abstract}

Keywords: Transfer of Rights; Land; Customary Law

\section{PENDAHULUAN}

Tanah adalah suatu yang mempunyai mutu yang begitu penting dalam kehidupan manusia, sebab tanah sama besar dengan keberlangsungan kehidupan manusia, dimana semua kebutuhan manusia 
untuk bertahan hidup bersumber dari tanah. Maka dari itu tanah dianggap sebagian banyak orang di Indonesia adalah Ibu, sama seperti halnya dengan ibu kita sendiri yang menghidupkn kita.

Pemindahan adalah kelakuan hukum yang dibuat-buat dengan haluan biar hak atas tanah bertukar dari yang mengalihkan kepada menerima pengalihan (Sutedi, 2008). Beralih yang dimaksud bukan terjadi karena satu perbuatan hukum (sengaja) tetapi dikarenakan peristiwa hukum (tidak sengaja), contohnya mewariskan, sedangkan "dialihkan" memperlihatkan adanya kesengajaan maka terdapat suatu kelakuan hukum dengan hak milik itu (Maulidi dkk., 2017).

Peralihan hak atas tanah adalah suatu proses bergantinya pemegang hak tanah yang dahulu ke pemengang hak tanah yang saat ini (Irvan dkk., 2019). Peralihan hak atas tanah memiliki 2 ragam peralihan hak atas tanah, adalah beralih dan dialihkan (Santoso, 1991). Beralih melihatkan bergantinya hak atas tanah tanpa ada perbuatan hukum yang dilaksanakan oleh empunya. Seperti melewati waris. Bedanya dialihkan merujuk terhadap bergantinnya hak atas tanah melewati perbuatan hukum yang dilaksanakan yang mempunyai, contohnya melewati jual beli.

Hak atas Tanah merupakan seseorang yang memiliki hak untuk berkuasa sebidang tanah yang bisa diibahkan kepada individu/perseorangan, perkumpulan orang, atau badan hokum (Santoso, 1991; Sutedi, 2008). Jenis hak atas tanah ada beragam, seperti hak milik, hak guna usaha, hak guna bangunan, hak pakai, dll (Irvan dkk., 2019). Tanah berkedudukan guna memberi pengayoman supaya tanah bisa di tata dengan rapi dan bisa membuat kehidupan rakyat lebih wajar sesuai dengan ketentuan dalam Pasal 27 ayat (2) Undang-Undang Dasar 1945.

Peralihan Hak atas Tanah menurut Hukum adat yaitu dimana ada yang memiliki tanah sebelumnya dan ingin mengalihkan haknya kepada yang ingin di alihkan dengan persetujuan atau saksi kepala desa dan masyarakat adat setempat. Denganadanya persetujuan dengan kepala desa dan masyarakat adat, maka sahnya Peralihan Hak atas Tanah dalam hukum adat tersebut. Kurangnya ada kekuatan hukum peralihan Hak atas tanah dalam hukum adat dalam Hukum di Indonesia akan menimbulkan suatu masalah terutama kurang taunya masyarakat di indonesia tentang Peraturan peralihan Hak atas tanah di indonesia.

Berdasarkan Uraian latar belakang di atas adapun rumusan masalah yang akan penulis bahas, yaitu:

1. Bagaimana tata cara peralihan Hak atas Tanah menurut Hukum Adat?

2. Bagaimanakah kekuatan Hukum jual beli Hak milik atas Tanah menurut Hukum Adat?

Setiap Penelitian pasti memiliki tujuan, adapun tujuan dari penelitian ini yaitu:

1. Untuk mengkaji dan menganalisis tata cara dalam peralihan Hak atas Tanah menurut Hukum Adat.

2. Untuk mengkaji dan menganalisis kekuatan Hukum jual beli Hak milik atas Tanah menurut Hukum Adat.

\section{METODE PENELITIAN}

Metode penelitian yang digunakan dalam melakukan penelitian ini yaitu metode penelitian hukum normatif yaitu dimana pengkajiannya berdasarkan atas bahan-bahan hukum dari literature (Efendi \& Ibrahim, 2018). Dalam penelitian ini penulis menggunakan pendekatan masalah yaitu pendekatam perundang-undangan dan konseptual. Pendekatan perundang-undangan ditelaah secara baik dan peraturan perundang-undangan tersebut juga berhubungan dengan maslah yang ada. Sedangkan pendekatan konseptual merupakan suatu pendekatan yang di dalam ilmu hukum ada dan berkembang pemikiran dan doktrin para sarjana.

Adapun sumber bahan hukum yang digunakan penulis akan digunakan yakni bersumber dari penelitian dan kepustakaan berupa:

1. Bahan hukum primer yaitu bahan-bahan hukum berupa peraturan perundang-undangan yakni: UUD 1945, UU No. 5/1960 tentang Ketentuan-Ketentuan Pokok Agraria, PP No.24/1997 tentang Pendaftaran Tanah. PP No. 37/1998 tentang Peraturan Jabatan PPAT, PMNA 3/1997 tentang Peratursn Pelaksanaan Pendaftaran Tanah.

2. Bahan hukum sekunder yaitu bahan-bahan hukum yang diperoleh dari pengakajian kepustakaan (Library Research) yaitu dengan membaca buku-buku hukum, jurnal-jurnal hukum, surat kabar dan juga dari internet yang berkaitan dengan permasalahan yang diteliti.

Teknik pengumpulan bahan hukum yang digunakan dalam peneliti ini adalah teknik dokumentasi yang dilaksanakan sesuai cara menginventarisasi dan mengkategorisasi bahan-bahan hukum baik peraturan perundang-undangan, literature-literatur maupun bahan hukum lainnya yang berkaitan 
terhadap peralihan hak atas tanah melalui jual beli menurut hukum adat. Selanjutnya dilakukan dengan metode pencatatan yaitu dengan cara mengutip, meringkas, dan memberikan ulasnan-ulasan dengan topik bahasan.

Setelah bahan hukum primer dan bahan hukum sekunder dikumpulkan, maka bahan hukum itu diolah dan dianalisis dengan metode pengolahan bahan hukum secara sistematis yaitu, dengan menggunakan argumentasi hukum berdasarkan logika dedukatif dan indukatif serta penyajiannya dilakukan dengan menyusun secara sistematis lalu diuraikan dalam bentuk deskripsi.

\section{HASIL DAN PEMBAHASAN}

\section{Tata Cara Peralihan Hak atas Tanah menurut Hukum Adat}

Sebelum membahas tentang peralihan Hak atas tanah menurut hukum adat dimana kita harus mengerti yang namanya tata cara, tata cara adalah kegiatan yang memiliki tahapan-tahapan agar tidak ada kekurangan dalam kegiatan tersebut maka isi tahapan-tahapan yang membuat kegiatan tersebut sempurna. Adapun tata cara dari peralihan hak atas tanah menurut hukum adat yang akan penulis bahas disini.

Hak atas tanah merupakan hak terhadap sebagian tertentu dari permukaan bumi, yang tidak banyak, berukuran dua dengan ukuran yang lebar (Perangin, 1991). Dasar pastinya hukum dalam peraturan hukum tertulis sesuai UUPA, memungkinkan para orang - orang yang berkepentingan dengan gampang mengetahui hukum yang belum kedaluarsa dan wewenang dengan kewajiban yang ada atas tanah yang dipunyai Hak-hak atas tanah mempunyai sifat penting dalam kehidupan manusia, makin majunya masyarakat, semakin lebih banyak penduduknya maka, akan memperbanyak lagi pentingnya kedudukan hak-hak atas tanah itu. Demikian dengan Undang-Undang Pokok Agraria No.5 Tahun 1960 (Lembaran Negara tahun 1960 No.104) telaah ditentukan, dasar tanah di seluruh wilayah NKRI, harus didaftarkan diinvetariskan. Pasal 19 ayat (1) UUPA berbunyi:

"Untuk menjamin kepastian hukum oleh Pemerintah diadakan pendaftran tanah, yang diatur dengan Peraturan Pemerintah" (Direktorat Jendral Agraria Departemen dalam Negeri, 1985).

Peralihan adalah sesuatu yang di alihkan dari pemilik yang sebelumnya ke pemilik yang baru. Ada 2 ragam peralihan hak atas tanah, yaitu beralih dan dialihkan. Beralih melihatkan kepada berpindah hak atas tanah tanpa ada perbuatan hukum yang dilakukan oleh pemiliknya, Seperti melalui waris. Sedangkan dipindahkan melihatkan pada berpindahnya hak atas tanah melewati perbuatan hukum yang dilakukan pemiliknya, seperti melalui jual beli.dan peralihan hak atas tanah menurut hukum adat adalah kegiatan yang mengalihan hak atas tanah dengan menggunakan konsep terang, tunai, riil. Terang adalah dimana kegiatan peralihan hak atas tanah dilakukan di hadapan umum, tunai adalah dimana pembeli harus memberikan uang tersebut dengan cara cash atau secara langsung, dan real adalah dimana kegiatan peralihan hak atas tanah tersebut dilakukan di hadapan 2 orang saksi dan pejabat pembuat akta tanah (PPAT) 2 orang saksi itu adalah masyarakat dan kepala desa setempat. Peralihan hak atas tanah bisa terjadi atau dilakukan karena pewarisan tanpa pewasiat dan perlakuan hukum pemindahan hak yaitu:

1. Pewarisan tanpa wasiat, yaitu peralihan hak atas tanah yang terjadi karena hukum dengan meninggalnya pemegang hak;

2. Pemindahan hak, yaitu peralihan hak atas tanah yang terjadi karena dibuat-buat dialihkan kepada pihak lain yang bentuk pemindahan haknya seperti :
1) Warisan
2) Hibah
3) Wasiat
4) JualBeli

Mekanisme atau tata cara dari peralihan hak atas tanah menurut hukum adat adalah dimana seseorang yang mau mengalihkan hak atas tanahnya kepada yang mau dialihkan dengan di hadapan kepala desa dan masyarakat setempat dan dihadapan pejabat pembuatan akta tanah dengan konsen terang, tunai, riil.

Mungkin di Indonesia masih banyak juga dari Adat-adat di Indonesia yang mungkin berbeda cara beralihnya hak atas tanah, maka dari itu penulis tidak bisa menjelaskan satu persatu tentang peralihan hak atas yang lainnya Cuma saja yang bisa penulis jelaskan disini adalah dengan cara umumnya adat 
di indonesa. Yang Cara beralihnya dengan cara di hadapan kepala desa setempat dan berserta saksisaksi dengan cara / konsep Terang, Tunai, dan riil.

\section{Kekuatan Hukum Jual Beli Hak Milik atas Tanah menurut Hukum Adat}

Masih berjalannya UUPA dengan peraturan prosesnya PP No. 10/1961 perihal Pendaftaran Tanah yang diperbaharui menjadi lebih sempurna dengan PP No. 24/1997 Tentang Pendaftaran Tanah, maka peralihan hak atas tanah melalui jual-beli yang sebelumnya cuma dapat dilaksanakan atau disahkan di hadapan kepala desa/adat dan tidak ditunjukkan dengan akta jual beli, maka sesuai dengan peraturan ini, peralihan hak atas tanah dengan proses jual beli harus menunjukkan akta dan dilaksanakan di depan pejabat yang berwenang.

akta jual beli adalah suatu syarat yang harus di buktikan supaya dapat dilaksanakannya pendaftaran sesuai yang diatur dalam Pasal 37 (1) PP No. 24/1997 Tentang Pendaftaran Tanah. Supaya bisa mendaftarkan tanah yang transaksinya dilaksanakan berdasar hukum adat sesudah berlaku PP No.24/1997 Tentang Pendaftaran Tanah, maka petama -tama pengulangan transaksi di depan PPAT untuk memperoleh akta dengan meminta Putusan Pengadilan Negeri yang menyatakan bahwa transaksi yang diperbuatan adalah sah berdasar hukum supaya mendapatkan surat penetapan dari Pengadilan Negeri agar dapat dilakukan pendaftaran.

Surat jual beli berguna untuk mempastikan kebaikan tentang keadaan tanahnya, pemegang haknya dan keabsahan bahwa telah dikerjakan setaraf dengan hukum dan disaksikannya jual beli tanah oleh Kepala Adat atau Kepala Desa dan Sekretaris Desa sebagai wakil dari Warga Desa tersebut, dan saksi-saksi. Jual beli tanah berdasarkan Hukum Adat meliputi unsur-unsur sebagai berikut:

1. Kesesuaian harga dan barang;

2. Pembayaran dan penyerahandilakuka secara serentak;

3. Dikerjakan secara tertulis (surat jual beli tanah) maupun secara lisan;

4. Dikerjakan dihadapan KepalaAdat/KepalaDesadanSekretarisDesa sebagaisaksi-saksi atas peristiwantersebut.

Di dalam Kitab Undang-Undang Hukum Perdata ketentuan tentang pembeli yang beritikad baik terdapat pada pasal 1338 ayat (3) yang menyebutkan:

"Suatu perjanjian harus dilaksanakan dengan itikad baik". Pasal ini bertujuan untuk mencegah perbuatan-perbuatan yang tidak patut dan yang bertentangan hukum serta untuk memberikan landasan perlindungan hukum atas suatu perbuatan jual beli bagi pembeli yang beritikad baik."

Pembeli yang beritikad baik maka ia harus dilindungi oleh hukum. Itikad baik dapat pula dilihat dari kenyataan dalam peristiwa hukum tersebut seperti:

1. Harus betul-betul tidak mengetahui kalau tanah yang dibeli itu adalah tanah bukan milik dari si penjual;

2. Jual beli dilaksanakan dengan terang dan disaksikan oleh Kepala adat.

Sahnya jual beli menurut hukum adat yaitu dimana si pembeli dan si penjual bertemu dan membuat perjanjian di hadapan kepala desa setempat bersertakan saksi, barulah sahnya itu perjanjian jual beli. dan jika mau sah secara peraturan/ secara kenegaraan PP no.24 tahun 1997 tentntang pendaftaran tanah perjanjian jual beli tersebut di lanjutkan ke PPAT ( Pejabat Pembuat Akta Tanah) setelah ke PPAT lanjut ke Notaris agar di daftarkan dengan sesuai denagn Peraturan di Indonesia.

\section{SIMPULAN DAN SARAN}

\section{Simpulan}

1. Peralihan hak milik atas tanah menurut hukum adat yaitu peralihan yang menggunakan konsep tunai, terang, dan riil, atau bisang di artikan secara cash, terbuka, dan secara nyata hanya dilaksanakan di depan kepala desa/kepala adat di sertai saksi-saksi, dalam peralihan hak atas tanah berdasarkan Hukum Adat yang dilakukan tanpa dihadapan PPAT (Pejabat Pembuat Akta Tanah) adalah sah sepanjang syarat materilnya terpenuhi.

2. Kekuatan hukum dari jual beli hak atas tanah menurut hukum adat terhadap pembeli yang beritikad baik sangatlah penting artinya. Pembeli yang beritikad baik merupakan bagian dari upaya perlindungan hukum terhadap pembeli dalam setiap transaksi jual beli hak atas tanah. Hal ini terlihat dari beberapa yurisprudensi Makamah AgungRepublik Indonesia. Tindakan jual beli 
yang beritikad baik terlihat pada saat orang - orang yang melakukan jual beli hak atas tanah meminta untuk dilakukan dihadapan Kepala Adat/ Kepala Desa setempat. Sah-sah saja jika jual beli dilalukan dalam hukum adat hanya saja itu sah dalam perjanjian jual beli bukan berarti itu sah dalam Kenegaraan yang di atur dalam Peraturan Pemerintah no. 24 tahun 1997 tentang pendaftaran tanah, dan dapat di simpulkan kekuatan hukum Peralihan hak atas tanah melalui jual beli menurut hukum adat diatur Didalam KUHPerdata perlindungan hukum kepada pembeli yang beritikad baik, apabila perjanjian jual beli dilakukan berdasarkan Hukum Adat telah dilindungi oleh ketentuan pasal 1338 ayat (3) KUHPerdata.

\section{Saran}

1. Setidaknya Negara yang mempunyai tanggungjawab dalam memberikan pengakuan, perlindungan dengan kepastian hukum kepada hak-hak masyarakat hukum adat menyangkut hakhak dasar yang dipunyai khususnya atas tanah-tanah adat. karena masyarakat- masyarakat yang tidak tahu cara peralihan ha katas tanah sangat mudah di bohongi jika masyarakat tersebut tidak mengetahui mekanisme dari beralihnya nama tanah.

2. Sebelum melakukan jual beli hak atas tanah, disarankan sebaiknya pembeli mengetahui dahulu informasi yang akurat baik pada Kantor Desa/Kelurahan maupun pada Kantor Pertanahan setempat mengenai status tanah yang akan diperjualbelikan. Karena meskipun undang-undang memberikan perlindungan hukum terhadap pembeli yang beritikad baik, akan tetapi hal tersebut bukan merupakan jaminan bagi pembeli akan terjadinya hal-hal yang tidak diinginkan dikemudian hari.

\section{DAFTAR PUSTAKA}

Direktorat Jendral Agraria Departemen dalam Negeri. (1985). Buku Tuntunan bagi Pejabat Pembuat Akta Tanah. Hudya Bina Sejahtera.

Efendi, J., \& Ibrahim, J. (2018). Metode Penelitian Hukum Normatif dan Empiris. Prenada Media.

Irvan, M., Warman, K., \& Arnetti, S. (2019). Proses Peralihan Hak Milik atas Tanah Karena Pewarisan dalam Perkawinan Campuran. LamLaj, 4(2), 148-161.

Maulidi, M. J., Arba, M., \& Aharuddin. (2017). Analisis Hukum tentang Peralihan Hak Milik atas Tanah dengan Bukti Akta di Bawah Tangan sebagai Dasar Pendaftaran Tanah untuk Pertama Kali (Studi di Kabupaten Lombok Tengah). Jurnal IUS, 5(3).

Perangin, E. (1991). Hukum Agraria Indonesia: Suatu Telaah dari Sudut Pandang Praktisi Hukum. Rajawali.

Santoso, U. (1991). Pendaftaran dan Peralihan Hak atas Tanah. Predana Media.

Sutedi, A. (2008). Peralihan Hak atas Tanah dan Pendaftarannya (1st ed.). Sinar Grafika.

Kitab Undang-Undang Hukum Perdata

Undang-undang No.5 Tahun 1996 tentang Peraturan Dasar Pokok Agraria

Peraturan Pemerintah No 24 Tahun 1997 tentang Pendaftaran Tanah

Peraturan Pemerintah No 37 Tahun 1998 tentang Peraturan Jabatan Pejabat Pembuat Akta Tanah (PPAT) 